\title{
О ПРИЈАТЕЉУ У СЛОВАЧКОЈ И СРПСКОЈ ЈЕЗИЧКОЈ СЛИЦИ СВЕТА*
}

Циљ рада је да истражи и опише стереотип пријатеља у словачкој и српској језичкој слици света на речничком језичком материјалу, у паремиологији и електронским корпусима словачког и српског језика, уз посебан осврт на новије колокације: слов. priatel' na facebooku/facebookový priatel', priatelia s benefitmi/priatelia s výhodami; срп. пријатељь емисије, пријатељь на Фејсбуку, пријатељи с повластицама. У теоријском смислу, испитује се да ли негативну раван стереотипа пријатеља чини стереотип непријатеља или, без обзира на творбени модел, стереотип непријатеља има сопствени координатни систем и семантички садржај.

Кључне речи: пријатељ, словачки језик, српски језик, когнитивна лингвистика, језичка слика света, стереотип.

The aim of the paper is to investigate and describe the stereotype of friend in the Slovak and Serbian linguistic world images on dictionary material, in paremiology and electronic corpora of the Slovak and Serbian languages, with special reference to newer collocations: priatel' na facebookulfacebookový priatel', priatelia s benefitmi/priatelia s výhodami; nријатељь емисије, пријатељь на Фејсбуку, пријатељи с повластицама. In theoretical terms, it is examined whether the negative plane of the stereotype of a friend is the stereotype of the enemy or, regardless of the word formation model, the stereotype of the enemy has its own coordinate system and semantic content.

Keywords: friend, Slovak language, Serbian language, cognitive linguistics, linguistic world image, stereotype.

Човек је друштвено биће. Он расте и развија се у неком друштвено-културном окружењу које га на различите начине обликује. Наш животни пут у великој мери зависи од тога какве људе на том путу срећемо, какве међуљудске односе градимо и са ким: $S$ kým si, taký si (Záturecký 1975: 155); C ким си онаки си, С ким си до подне онаки си по подне или $C$ каким си до подне онаки си од подне, С ким те виде с тијем те и пииу (Караџић 1969: 287). Наше понашање, мишљење, просуђивање и говорење у основи одсликавају моделе понашања, мишљења, просуђивања и говорења којима смо изложени. Овакво преузимање фрагмената „колективне конвенционалне језичке слике света” представља стереотип (Поповић 2008: 63), те га можемо дефинисати као „скуп вредносних критеријума за процену чланова (елемената) неке категорије издвојених на основу статуса и функционалних атрибута које та категорија има у датој култури

* Рад је настао у оквиру међуакадемијског билатералног пројекта New words, new media, new social and language tendency in Serbia and Slovakia (Нове речи - нови медији - нове тендениије у језику и друштву у Србији и Словачкој; број пројекта: SASA-SAS-21-04), који се реализује при Српској академији наука и уметности и Институту за српски језик САНУ у сарадњи са Институтом за лингвистику „Људовит Штур” Словачке академије наука. 
или друштву" (Пауновић Родић 2019: 44). Иако координатни систем стереотипа чине позитивна и негативна раван (Поповић 2008: 63), он је по својој природи позитиван, јер има за циљ да промовише оне карактеристике неког елемента ванјезичке стварности који се у датој (говорној) средини процењују као пожељне или потребне (Пауновић Родић 2019: 44).

Циљ овога рада јесте да испита стереотип пријатеља у словачкој и српској језичкој слици света и осветли сличности и разлике у концептуализацији и категоризацији овог појма. Интересовање за истраживање стереотипа пријатеља потекло је од уочавања извесних иновација у употреби овог појма у савременом словачком и српском друштву, нпр.: пријатељ емисије, пријатељ с повластицама, пријатељь на Фејсбуку. Ове колокације навеле су нас да се посебно позабавимо трима питањима која се тичу категоризације: прво, да ли се и када пријатељ употребљава да означи учесника у односу из сфере јавног живота; друго, да ли се и када пријатељем може назвати особа са којом се остварује интимни однос; треће, како је употреба друштвених мрежа утицала на семантички обим овог појма и уопште на концептуализацију пријатељског односа. На теоријском плану, у смислу разраде теорије стереотипа, испитаћемо да ли стереотип пријатеља има негативну раван или ћемо описом негативног пола семантичког поља стереотипа пријатеља закорачити у опис категорије непријатеља, с обзиром на творбени модел антонима.

Словачко priatel' и српско пријатељь изводе се из индоевропског *prāi-, *prəi, *pri- (*pri-) те прасловенског *prbjati одн. *prijati у значењу онај који нам прија, ко нам је наклоњен, који нас воли, али и у значењу сродника (Skok II: 4041; Králik 2015: 471-472; Machek 1968: 490-491; Rejzek 2001: 511).

Паремиолошки корпуси словачког и српског језика релативно су богати примерима с темом пријатељства што говори о томе да је пријатељство веома важан међуљудски однос у традицији ова два народа. Паремиолошке примере можемо сврстати у неколико група, а пре свега у оне које одражавајуу еквивалентну или блиску концептуализацију и оне које потврђују разлике у виђењу овог појма. У наставку ћемо их наводити управо тим редом.

У паремиологији словачкој и српског језика примећујемо да се пријатељски однос високо цени, сматра важним: слов. Priatel'ov a zdravia nikdy nemáme dost' (Záturecký 1975: 76), Dobre tomu, kto má priatel'ov, beda tomu, kto ich potrebuje (Záturecký 1975: 139), Dobrého priatel'a si váž ako drahý poklad (Záturecký 1975: 139), Dobrý priatel' nad zlato (Záturecký 1975: 139), Lepšia hrst' priatel'stva ako voz dukátov (Záturecký 1975: 140), Lepšie je mat'sto priatel'ov ako jedného nepriatel'a (Záturecký 1975: 140), Lepšie mat' priatel'ov ako nepriatelov (Záturecký 1975: 140), Lepšie priatel'stvo ako peniaze (Záturecký 1975: 140), Kto priatel'a miluje, svojho nelıutue (Záturecký 1975: 140); срп. Добро је и у паклу имат ' пријатељь а (Караџић 1969: 60), Док је Бога и добријех пријатеља, донде се ништа не ваља бојати (Караџић 1969: 64), Не остави, Боже, без пријатељь (Караџић 1969: 207).

Паремиологија оба језика богата је пословицама које упозоравају да је 'прави', ‘добар' пријатељ онај који помаже, који је ту када је тешко, те да је 'неправи', 'непроверен' пријатељ онај који је ту само у благостању, што уједно 'старог' пријатеља чини важнијим и вреднијим од 'новог': слов. Dobrá studňa v suchu vodu 
dáva: dobrý priatel'v núdzi sa poznáva (Záturecký 1975: 139), Ak máš plný mešec, priatelia t’a nájdu (Záturecký 1975: 77), Ak máš meštek ako tel'a, máš rodinu i priatel'a; ak máš meštek ako lata, nemáš sestry ani brata (Záturecký 1975: 77), Mám rodiny ako v plote tŕniny, ale priatel'a čert vzal, čo by mi dačo dal (Záturecký 1975: 77), Nie to priatel', čo miluje v štastí, ale ktorý pomáha v nešt’astí (Záturecký 1975: 140), V potrebe priatel'a poznáś (Záturecký 1975: 140), Zlato sa probuje v ohni a priatel'v nešt'astí (Záturecký 1975: 140), Dobrí priatelia sa s jednou jahodou podelia (Záturecký 1975: 140), Priatel'ovi aj o polnoci (pomôžem) (Záturecký 1975: 140), Nových priatel'ov nadobudni, starých nezabudni (Záturecký 1975: 140), Pri nových priateloch nezabúdaj na starých (Záturecký 1975: 140), Starý chlieb, staré víno, starý priatel' vždy dobrý (Záturecký 1975: 140), Starý priatel', staré víno najlepšie (Záturecký 1975: 140), Starodávny priatel' je najlepši (Záturecký 1975: 140); срп.: Злато се у ватри пробира а чоек у несрећи (Караџић 1969: 91); Пријатељ се у невољи познаје као злато у ватри (Караџић 1969: 262); Кад се једе и пије онда је доста пријатеља (Караџић 1969:120), Држ' се нова пута, стара пријатеља (Караџић 1969: 70).

У оба језика се у пословицама фокусира и танка граница између пријатеља и непријатеља: слов. Priatel'stvo blízko nepriatel'stva býva (Záturecký 1975: 140); срп. Препријатељь - непријатељ (Караџић 1969: 261; РMC IV: 978).

Следећу групу чине пословице у којима се пријатељство доводи у везу са сродством, при чему се ова тема обрађује више у словачкој паремиологији. Можемо издвојити за оба језика примере у којима се крвно сродство сматра пријатељством: слов. Kmotrovstvo, švagrovstvo — najhoršie priatel'stvo (Záturecký 1975: 77), Kmotrovstvo z lásky, priatel'stvo z krvi (Záturecký 1975: 77); срп. Тако ми братске љубави! Пријатељу. (Караџић 1969: 300).

У словачкој паремиологији бележимо и супротне примере, у којима се пријатељство цени више од сродства: Priatel' pánboh a rodina meštek (Záturecký 1975: 78), Rodiny do psej hodiny, ale priatel’čeka ani ako palčeka (Záturecký 1975: 78).

Пословице на словачком језику сведоче о томе да се пријатељски однос познаје и по томе што се након свађе пријатељи лако помире, као и да је критика пријатељски чин: Priatelia ako sa povadia, tak sa zase pomeria (Záturecký 1975: 78), Priatelia ako sa povadia, tak sa zase udobria (Záturecký 1975: 78), Kto t’a napomína, maj ho za priatel'a (Záturecký 1975: 140).

У српској паремиологији потврду оваквог става не налазимо - напротив, у српским пословицама фокусира се немогућност промене односа у смеру непријатељ-пријатељ: Док ја гледам мој реп, а ти свога сина гроб, нема правог пријатељства међу нама (Караџић 1969: 63-64); У стара крвника нема нова пријатељь, У старом душианину нема новог пријатеља (Караџић 1969: 336).

У описним речницима словачког и српског језика бележе се следећа заједничка значења и употребе: 1) особа са којом нас спаја узајамно поверење и наклоност или близак познаник с којим се одржавају везе узајамне љубави, поштовања и поверења, нпр.: слов. starý priatel', verný priatel', priatel' zo školských čias; срп. стари пријатељ, верни пријатељ, пријатељь из школских дана; 2) присталица приврженик, бранилаu, слов. prívrženec, priaznivec, podporovatel', stúpenec и 3) у обраћању непознатој особи, нпр.: слов. vážení priatelia, milí priatelia; срп. поитовани пријатељи, драги пријатељи (KSSJ; SSJ; PCJ: 1023; PMC V: 56-57). 
У речницима српског језика наводе се још два значења: 1) отаи једног од брачних другова према оиу другог брачног друга и 2) љубавник (РС : 1023; PMC V: 56-57). За прво од два додатна значења у словачком језику користи се реч svat и описује се као таст и свекар у односу један према другом и према супрузи оног другог (KSSJ; SSJ), а изводи се из индоевропског *seue-, *sue- те прасловенског *svatb у изворном значењу свој, лични, сопствени од чега се даље изводи онај који припада свом, властитом роду, рођак (Králik 2015: 568). Изворно значење сродника препознајемо и у жаргонском обраћању пријатељу именицом брат у српском језику (Gerzić 2012: 38), што се бележи и у речнику синонима словачког језика - brat, bratec, braček (SynSS) али и у историјском речнику словачког језика у значењу крвног сродника уз потврде у споменицима из XV, XVI, XVII и XVIII века (HSSJ). Друго значење - љубавник, описни речници словачког језика не бележе, али у речнику синонима из 2005. године налазимо да се слов. priatel' еуфемистично користи и у значењу слов. milenec (срп. љубавник; SynSS).

Синонимски ред именице priatel' у словачком језику употпуњује семантички потенцијал ове речи забележен у једнојезичним речницима и заокружује примере употребе које познајемо из језичке праксе. Тако ћемо у речнику синонима за одредницу priatel' поред очекиване синонимије у складу са првим и другим наведеним значењем у описним речницима (1) kamarát, druh, svoji, tovariš, súdruh, drusa, pajtáś, pusipajtáš, kmotor, bratec, braček, kamoš, kompán, kumpán, 2) privvrženec, zástanca, nasledovatel', nasledovnik, pokračovatel', žiak, odchovanec, vyznávač, škola, priaznivec, podporovatel', zástavnik, fanúšik, skalný, kmotor, stranik, svoji; SynSS) наћи и потврду за значење дечко или момак, тј. партнер y, обично младалачком, не брачном, али интимном емотивном односу који се може, али не мора завршити браком (уп. РСJ: 261, 244, 713), ${ }^{1}$ тј. мушкараи у ьубавном односу са, обично слободном, женом: chlapec, frajer, štramák, fešák, gavalier, svoj, l’ubimec, galán, šamster (SynSS).

Синонимски ред именице срп. пријатељ такође је дуг: друг, другар, познаник, дружбеник, сапатник, садруг, компањон, пријашко, судруг, другарчина, прико, сапутник, јаро, јаран, пајдаш, брат, бата, прикан, пријан, пајташ, ортак, пајтос, френд, камерад, колега, врињак, побратим (Һосић 2008: 499).

Видимо да се у оба језика пријатељским могу назвати различити, врло изнијансирани међуљудски односи (од познаника, преко колеге, вршњака и родбинских веза, до интимних веза) као и да пријатељем у обраћању можемо назвати и непознату особу. Ово говори у прилог мирољубивости, благости и хуманости као традиционалним вредностима у словачком и српском друштву. Додатну потврду за овакав закључак даје нам и значење именице слов. človek и срп. човек - људско биће са високим моралним и карактерним особинама, хумана особа, особа са позитивним људским особинама (PCJ: 1488; PMC VI: 891; SSSJ; уп. слов. nečlovek и срп. нечовек) као и придева слов. l'udský, срп. љьудски човечан, хуман, племенит, саосећајан, пријатељски, добар, поштен (РСЈ: 647; PMC III: 260; SSSJ; уп. слов. neludský, срп. нељудски).

${ }^{1}$ Очекујемо да ће се ово значење наћи у неком од следећих томова речника савременог словачког језика (Slovník súčasného slovenského jazyka). До сада су изашла три тома $(A-G$, $H-L, M-N$; в. SSSJ). 
Видели смо да се именицом слов. prijatel' и срп. пријатељ могу, обично еуфемистично, означити и учесници у емотивном интимном односу. Треба при томе имати на уму да се у традиционалном словачком и српском друштву рано ступало у брак, да је предбрачни интимни однос био често табуизован (ради женске чедности и части; в. Пауновић Родић 2019: 101-105), али и толерисан док не дође до трудноће (EL'K) те је сваки други, ванбрачни интимни однос, називан љубавничким. ${ }^{2}$ Из угла савременог живота, када су људи много слободнији да граде најразличитије врсте односа (отворене везе, отворене бракове, невенчане бракове и сл.), важно је водити рачуна о томе да слов. milenec/milenka и срп. љубавник/љубавница подразумевају да је бар један од учесника у односу заузет, тј. да има сталног партера, који (подразумева се) не зна (или бар не званично) за тај други однос, да је то тајни однос и обавезно, али не само, интиман. Уколико двоје живе у невенчаном браку ${ }^{3}$, у словачком језику ће се звати $d r u h /$ družka (KSSJ; SSSJ) што је именица која се такође јавља у синонимском реду именице priatel' (в. више). Ово значење бележе само новији речници (уп. druh y SSJ) што свакако говори о скорашњој легитимизацији оваквог односа у словачком друштву. У српском језику за овакав однос може се користити именица партнер/партнерка, мада речници овом смислу бележе само значење брачни друг, супружник (PCJ: 900; PMC IV: 344) или ће се означити описно невенчани супруг/муж, невенчана супруга/жена. У српском говорном језику примећујемо да се животна доб такође узима у обзир када су у питању емотивни односи, па ћемо пријатељ/пријатељица, превасходно при представљању, користити да еуфемистично означимо људе зрелих година у ванбрачном односу или невенчаном браку при чему тај однос бар за једног од њих није први и условно трајни такав однос (једно од њих је удовац/удовица или је разведено и сл.) ${ }^{4}$, али овај израз није адекватан за млађе парове.

У савременом словачком и српском језику примећујемо да се појавила колокација слов. priatel's benefitmi или priatel's výhodami, срп. npujameљ c noвластицама као калкирани израз из енглеског језика friends with benefits. Овај израз користи се да означи пријатеље који ,једно другом довољно верују да могу да се упусте у повремени сексуални однос без бојазни да ће емотивно повредити једно друго"5 (UD; превод С. П. Р.). То је такође однос за који се не

${ }^{2}$ Интересантно би било у овом контексту поменути да су некада, а опет не тако давно од друге половине XX века, постојали студентски домови за брачне парове, слов. manželské internáty или manželáky. У Словачкој, у Братислави се један студентски дом и даље тако зове, али више није пракса да се ту смештају студентски брачни парови (в. https://mlyny.uniba.sk/ o-nas/manzelske-internaty/). У Београду, на Вождовцу, још 1949. године, изграђен је овакав интернат и звао се Дом лордова, а на том месту је данас Студентски дом „4. април” (в. http:// sc.rs/sc/4-april/).

${ }^{3}$ Невенчани брак није новост у словачком и српском друштву о чему говоре фразеологизми слов. Pod vŕbou zosobáśsení (Záturecký 1975: 57); срп. венчати се око врбе (под врбом) (РСАНУ 2: 517; РСAHУ 3: 24).

4 За овакву употребу тешко је наћи примере у електронском корпусу и уопште у писаној форми који ће доказати описани контекст, јер се ради о говорној употреби у приватној сфери. Свакако треба додатно испитати ову употребу.

${ }^{5}$ „Two friends who trust each other enough to engage in sexual activity without fear of hurting 
очекује да ће прерасти у пуноправни, традиционално схваћен партнерски однос. Наравно, у односе које бисмо данас назвали пријатељи с повластицама су људи сасвим сигурно ступали и пре него што се појавила потреба за његовим именовањем, али су се сада у српском и словачком друштву створили услови да он сме као такав и да се „обелодани” а да ли је за тим заиста постојала потреба или је то питање моде и глобализације, питање је да ли можемо знати.

Именице слов. priatel' и срп. пријатељ срећемо и у колокацији слов. priatel' na Facebooku, facebookový priatel' и срп. пријатељь на Фејсбуку, што је такође калк из енглеског језика који се проширио употребом социјалне мреже Фејсбук. У овој колокацији, компоненту пријатељь на свим језицима треба тумачити као термин који је понуђен у оквиру друштвене мреже Фејсбук да означи особу с којом имамо директан контакт преко те друштвене мреже при чему није неопходно да та особа има статус пријатеља у традиционалном смислу изван ове мреже, али може имати. Могло би се закључити да је термин скован врло сугестивно да би корисници мрежа са својим контактима потенцијално доживели јачу емотивну везу него што она јесте како би их то додатно везало за употребу ове социјалне мреже, али заправо се ради о разлици у семантичком обиму концепта friend у енглеском језику и прuјameљ и priatel' у српском и словачком језику. На ове разлике упозорила је и Ана Вјежбицка, поредећи концепт пријатеља у енглеском, пољском и руском језику (Wierzbicka 1997: 32 124). Кључна разлика је у томе што концепт енгл. friend не укључује ни љубав ни међусобно поверење (Wierzbicka 1997: 120) те долази до погрешног, сугестивног утиска. На истраживање А. Вјежбицке, надовезује се и рад Алексеја Д. Шмељова (Шмелев 2005) и обоје закључују да је у руској култури, а то можемо рећи и за словачку и српску, важан критеријум пријатељства пружање помоћи и подршке онда када је то потребно.

Колокацију пријатељ емисије у којој се именица пријатељ користи у значењу спонзора, финансијера, не налазимо у том облику у словачком језику. Ово значење ослања се на друго наведено значење лексеме пријатељ у описним речницима српског језика - присталица приврженик, бранилац (РС : 1023; РМС V: 56-57) уз проширење у смеру добротвор, доброчинитељ (РСJ: 279). Иако се и у описним речницима словачког језика наводи овакво значење (в. више), проширење ка употреби спонзор, финансијер не бележимо. У енглеском језику постоји колокација friend of the show која се користи да означи сталног госта емисије, верног гледаоца који се често јавља директно у програм и сл. (в. UD).

У електронском корпусу српског језика (srWaC) пронашли смо седам примера са колокацијом prijatelj emisije/prijatelji emisije ${ }^{6}$. Примећујемо да постоје три типа примера. Прву и најбројнију групу чине примери код којих је јасно да се ради о спонзору емисије (подвукли смо их једном иртом), у другој групи су примери код којих видимо да је у питању калк из енглеског језика са значењем верних гледалаца/слушалаца (подвукли смо их двема цртама; ради се о једном примеру) а у трећој групи су примери код којих, чак и уз увид у шири контекст, није у потпуности јасно на које се од ова два значења мисли (подвукли смо их

the other's feelings."

${ }^{6}$ Примере наводимо изворно, без интервенција. 
таласастом иртом): Prijatelji emisije Škul TV su kuće koje na najvišem nivou doprinose misiji; Od 11. februara 2010. godine logo naše škole postavljen je na početnoj i odjavnoj špici Škul TV u kategoriji «Prijatelji emisije»; U aprilu mesecu škola Softline je postala prijatelj emisije Radna Akcija tako što smo im poklonili besplatan vaučer za kurs iz WEB DIZAJNA; Ako ćemo pošteno, reklama ima mnogo više. Cure na sve strane, upisuju se kao sponzorstva ili tehnička podrška programima. Tu su $i$ takozvani prijatelji emisije prvi na odjavnoj špici; U muzičkom delu emisije nastupiće kruševački bend DFB, a prijatelj emisije je Cafe Arabika; ZAIR je na OK radiju premijerno ponedeljkom u 16.00 i reprizno subotom u 17.00 časova. Ovo obaveštenje namenjeno je prijateljima emisije iz dalekog sveta, ali i svim ostalim slušaocima koji su van FM dometa naše emisije, a pri tom žele da čuju malo više od skraćene verzije ZAIRA ponudjene na ovom sajtu; Prijatelji emisije izdavačke kuće Prometej i Klio vas nagrađuju, a vodimo vas $i$ u Narodno pozorište večeras. Примера преко интернет претраживача има много више. За упит „prijalj emisije“ интернет претраживач Гугл нуди три хиљаде триста тридесет интернет страница на којима се ова колокација употребљава, а за упит „prijatelji emisije“ три хиљаде сто шездесет. ${ }^{7}$ Ако изузмемо интернет странице за онлајн куповину које нам је интернет претраживат понудио за овај упит, међу осталим примерима доминантни су они са значењем спонзора: Prijatelji emisije $i$ ove sezone su Idea prodavnice ${ }^{8}$ PRIJATELJI EMISIJE ${ }^{9}$ (као поднаслов изнад имена фирми које су финанскијски помогле емисију); I dok je Dragana govorila ko su prijatelji emisije, Žika se dosetio da odglumi svaku reklamu, a posebno inspirativna mu je bila ona za Net TV Plus ${ }^{10}$; U osmomartovskom izdanju, prijatelji emisije su darovali dame па praznik ${ }^{11}$. Напли смо и примере у којима се ради о значењу преузетом из енглеског језика те се тражена колокација односи на сталне или честе госте неке емисије: Rođendansko veselje uveličali su i dragi prijatelji emisije Za Beograd. Ljudi koji su rado i često bili gosti i govorili o svim onim blagodetima glavnog grada, o svojim uspomenama, ljubavima u ovom gradu, o svojim planovima i željama ${ }^{12}$. Има и примера у којима се значење колеба: Dragi naši slušaoci i prijatelji emisije Obavezno-Neobavezno, verovatno ste primerili (bar petnaestak vas koji nas sluša) da emisije danas nije bilo, kao i većeg dela govornog programa radija Laguna ${ }^{13}$; Prijatelji Bunt Rok Festivala RTS- a su ujedno i dugogodišnji prijatelji emisije Bunt, koji su prepoznali značaj jedine televizijske rok emisije, ali i jedinog televizijskog muzičkog festivala takmičarskog karaktera koji promoviše mlade i neafirmisane sas-

\footnotetext{
${ }^{7}$ Наведени упити претраживани су 18. јула 2021. године.
}

8 https://www.vijesti.me/tv/emisije/487275/dnevnica-sa-ivanom-mrvaljevic-citav-dan-sa-kacigomna-glavi

${ }^{9}$ http://www.loviribolovtv.com/o-nama.html; http://www.emisijafarma.rs/; https://www.malidnevnik.rs/cr/; https://beguprirodu.rs/\#prijatelji; https://pureallure.co/tag/tvnasa/

10 https:/grand.online/nikad-nije-kasno/news/u-svaku-sobu-po-televizor-i-da-gledate-nikad-nijekasno-video

${ }^{11} \mathrm{https}$ //lat.rtrs.tv/program/tekst.php?id=2284

12 https://informer.rs/zabava/kultura/336571/foto-cetvrti-rodjendan-emisije-beograd-poznatiuvelicali-slavlje

${ }^{13}$ https://direktno.rs/zivot/302738/zeljko-mitrovic-smiljan-banjac-igor-brakus.html 
tave $i$ autore. ${ }^{14}$ Можемо закључити да је колокација пријатељ емисије настала под утицајем енглеског израза friend of the show, мада се у значењу и употреби у највећем броју примера ослања на унеколико проширен, али познати семантички садржај уз извесна периферна колебања у смеру значења енглеског израза.

Следећи корак у нашем истраживању јесте испитивање колокабилности именице слов. priatel' и срп. пријатељ у електронским корпусима словачког (Slovenský národný korpus - SNK) и српског језика ( $\mathrm{srWaC})$. Наведене именице задали смо као леме и испитивали смо њихов најужи леви контекст. У обзир смо узимали оне колокате који имају фреквенцију појављивања најмање 0,1\% у односу на укупан број појављивања именице слов. priatel' и срп. пpujameљ у корпусу (слов. priatel' укупно у SNK 249131; срп. пријатељ укупно у srWaC 108465).

Истраживање колокација у електронским корпусима, као што ће се видети из формираних група колоката, потврђује централна значења и употребе који су забележени у претходно представљеној и анализираној грађи и указују на висок степен еквиваленције у колокабилности слов. priatel' и срп. пријатељ.

С обзиром на наведена ограничења издвојили смо следеће групе колоката.

У прву и најбројнију групу колоката у оба истраживана језика спадају присвојне заменице у коју смо уврстили и придев слов. spoločný и срп. заједнички

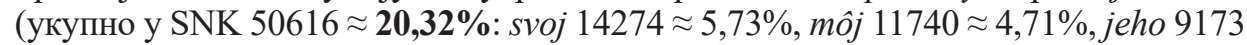
$\approx 3,68 \%$, náš $4253 \approx 1,71 \%$, váš $3738 \approx 1,5 \%$,jej $3513 \approx 1,41 \%$, tvoj $1787 \approx 0,72 \%$, ich $1660 \approx 0,67 \%$, spoločný $478 \approx 0,19 \%$; укупно у $\operatorname{srWaC} 21811 \approx \mathbf{2 0}, \mathbf{1 1 \%}$ : svoj $5716 \approx$ $5,27 \%$, moj $5207 \approx 4,8 \%$, vaš $3854 \approx 3,55 \%$, njegov $2477 \approx 2,28 \%$, naš $2251 \approx 2,08 \%$, njihov $937 \approx 0,86 \%$, njen $608 \approx 0,56 \%$, tvoj $409 \approx 0,38 \%$, zajednički $352 \approx 0,32 \%$ ).

У другој најбројнијој групи колоката за оба истраживана језика су придеви којима се посредно, карактеришући пријатеља, заправо позитивно квалификује пријатељски однос (укупно у SNK $34126 \approx \mathbf{1 3 , 7 0 \%}$ : dobrý $10794 \approx 4,33 \%$, blizky $4495 \approx 1,8 \%$, starý $3288 \approx 1,32 \%$, nový $2468 \approx 0,99 \%$, milý $2077 \approx 0,83 \%$, drahý $1709 \approx 0,69 \%$, dlhoročný $1322 \approx 0,53 \%$, osobný $1183 \approx 0,47 \%$, verný $1067 \approx 0,43 \%$, rodinný $1056 \approx 0,42 \%$, vel'ký $977 \approx 0,39 \%$, skutočný $861 \approx 0,35 \%$, dôverný $720 \approx$ $0,29 \%$, dávny $628 \approx 0,25 \%$, vážený $444 \approx 0,18 \%$, ozajstný $277 \approx 0,11 \%$, rodina $302 \approx$ $0,12 \%$, d'alši $458 \approx 0,18 \%$; укупно у srWaC $13479 \approx \mathbf{1 2 , 4 3 \%}$ : dobar $3886 \approx 3,58 \%$, drag $1731 \approx 1,6 \%$, velik $1694 \approx 1,56 \%$, blizak $1625 \approx 1,5 \%$, star $993 \approx 0,92 \%$, nov $942 \approx 0,87 \%$, prav $908 \approx 0,84 \%$, iskren $449 \approx 0,41 \%$, dugogodišnji $414 \approx 0,38 \%$, ličan $251 \approx 0,23 \%$, kućni $209 \approx 0,19 \%$, veran $205 \approx 0,19 \%$, porodični $185 \approx 0,17 \%$, odan $132 \approx 0,12 \%$, osvedočen $128 \approx 0,12 \%$ ).

Наредну, трећу групу чине квантификатори (укупно у SNK $4119 \approx \mathbf{1 , 6 5 \%}$ : vel'a $1662 \approx 0,67 \%$, jediný $418 \approx 0,17 \%$, skupina $405 \approx 0,16 \%$, niekol'ký $386 \approx$ $0,15 \%$, okruh $384 \approx 0,15 \%$, mnohý $352 \approx 0,14 \%$, mnoho $314 \approx 0,13 \%$, množstvo 278 $\approx 0,11 \%$; укупно у $\operatorname{srWaC} 1836 \approx \mathbf{1 , 6 9 \%}$ : grupa $322 \approx 0,3 \%$, brojan $303 \approx 0,28 \%$, puno $226 \approx 0,21 \%$, lista $246 \approx 0,23 \%$, nekoliko $205 \approx 0,19 \%$, dosta $174 \approx 0,16 \%$, jedini $131 \approx 0,12 \%$, mnogobrojan $120 \approx 0,11 \%$, par $109 \approx 0,1 \%$ ).

За разлику од прве три групе, у којима слов. priatel' и срп. пријатељ иступају у свом првом значењу - особа са којом нас спаја узајамно поверење и наклоност

\footnotetext{
${ }^{14}$ https://www.rts.rs/page/tv/sr/story/22/rts-svet/3545287/bunt-rok-festival---specijal.html
} 
или близак познаник с којим се одржавају везе узајамне ьубави, поштовања и поверељ $a$, у четврту групу смо сврстали именице са којима се слов. priatel' и срп. пријатељ у виду неконгруентног атрибута појављују у другом значењу срп. присталица, приврженик, бранилас, слов. prívrženec, priaznivec, podporovatel', stúpenec (укупно у SNK $5457 \approx \mathbf{2 , 1 9 \%}$ : Klub $1284 \approx 0,52 \%$, Spoločnost' 999 $\approx 0,4 \%$, klub $845 \approx 0,34 \%$, kruh $798 \approx 0,32 \%$, spoločnost' $603 \approx 0,24 \%$, združenie $548 \approx 0,22 \%$, Spolok $377 \approx 0,15 \%$; укупно у $\operatorname{srWaC} 1158 \approx \mathbf{1 , 0 7 \%}$ : društvo $471 \approx$ $0,43 \%$, krug $399 \approx 0,37 \%$, klub $148 \approx 0,14 \%$, udruženje $140 \approx 0,13 \%$ ).

У посебну, пету групу сврстали смо оне именице које указују на помоћ или подршку (у SNK само ротос $386 \approx \mathbf{0 , 1 5 \%}$; укупно у srWaC $678 \approx \mathbf{0 , 6 3 \%}$ : pотос́ $540 \approx 0,5 \%$, podrška $138 \approx 0,13 \%$ ).

Као шеста, издвојила се група колоката који упућују на употребу именице слов. priatel' и срп. пријатељ у јавној сфери, претежно политичкој, у значењу савезник, при чему је с обзиром на ограничења која смо поставили у корпусној анализи, израженија у корпусу српског језика (у SNK само americký $261 \approx \mathbf{0 , 1 \%}$; укупно у srWaC $1069 \approx \mathbf{0 , 9 9 \%}$ : zapadni $347 \approx 0,32 \%$, sportski $181 \approx 0,17 \%$, evropski $149 \approx 0,14 \%$, poslovan $141 \approx 0,13 \%$, politički $132 \approx 0,12 \%$, američki $119 \approx$ $0,11 \%)$.

Као колокати именице слов. priatel' и срп. прujameљ иступили су и глаголи који говоре о постојању, непостојању, стицању пријатеља или о начину успостављања контакта између пријатеља (укупно у SNK $4562 \approx \mathbf{1 , 8 3 \%}$; mat' $2265 \approx 0,91 \%$, nemat' $522 \approx 0,21 \%$, nájst' $507 \approx 0,2 \%$, stat' $348 \approx 0,14 \%$, hl'adat' 328 $\approx 0,13 \%$, stretnutie $324 \approx 0,13 \%$, navštivit' $268 \approx 0,11 \%$; укупно у srWaC $2344 \approx$ $\mathbf{2 , 1 6 \%}$ : imati $1092 \approx 1,01 \%$, poštovati $348 \approx 0,32 \%$, postati $269 \approx 0,25 \%$, nemati 252 $\approx 0,23 \%$, pozvati $219 \approx 0,2 \%$, steći $164 \approx 0,15 \%$ ).

Као последњу, осму по реду, наводимо групу колоката која фокусира негативне карактеристике пријатеља (срп. лажни) или последицу пресупонираног 'недоброг' пријатељског односа у виду прекида пријатељства (у SNK само bývalý $1002 \approx \mathbf{0 , 4 \%}$; укупно у $\operatorname{srWaC} 250 \approx \mathbf{0 , 2 3 \%}$ : lažan $110 \approx 0,1 \%$ (уп. falošný $148 \approx 0,06 \%$ ), bivši $140 \approx 0,13 \%$ ), али треба водити рачуна да у овом случају колокација слов. bývalý priatel' не значи само срп. бивщи, некадашюи пријатељ, већ и бивши момак/дечко те би се тиме могла правдати знатно већа фреквенција колоката слов. bývalý у односу на срп. бивии. Колокације слов. falošný priatel, bývalý priatel' чине део негативне равни стереотипа пријатеља, а да ли је део те равни и концепт непријатеља испитаћемо у наставку.

Именица слов. nepriatel' и срп. непријатељ у описним речницима словачког и српског језика једнако се дефинише: 1. онај који некоме жели или наноси зло 2. вој. онај против кога се води оружани рат 3. а. онај који се бори против нечега што сматра штетним, противник; б. оно што наноси штету, болест, несрећу и сл. (РС : 809; уп. РМС III: 741-742; SSJ; KSSJ) и не наводи се као антоним при речничком опису слов. priatel' и срп. пријатељь и обрнуто. Једини изузетак у том смислу представља опис у речнику савременог словачког језика у којем се као прво значење управо наводи да је непријатељ онај ко не пружа уточиште, не опходи се као пријатељ, већ с отпором, нападачки с ицљем да нашкоди (SSSJ). У српском језику у прилог праве антонимије овог пара гово- 
ре резултати асоцијативног теста тиме што се показало на јакој, двосмерној, асоцијативној вези између речи пријатељ и непријатељ (ОАР: 7-8, 481), а знамо да ако „лексема поседује антоним и независно од контекста и у контексту, он ће увек бити фреквентнија асоцијација испитаника на ту лексему од оне лексеме која је антоним само у контексту” (Драгићевић 2007: 265). Ипак, слов. priatel' и nepriatel' и срп. npujaтељь и непријатељь не могу бити прави антоними зато што им се супротстављају само основна, али не и друга значења (уп. (*непријатељь емисије, *непријатељь на Фејсбуку, *непријатељь са повластицама, отаи једног од брачних другова према оиу другог брачног друга - супр. *непријатељ; Драгићевић 2007: 266), тј. префиксом не- овде се одриче само основно значење антонимског пара. ${ }^{15}$

Слов. priatel' и nepriatel' и срп. nријатељь и непријатељ можемо описати као контрарно-координиране појмове (кохипониме) чији је надређени појам (хипероним) међуљудски однос (в. Књазев-Адамовић, Новаковић 1986: 27-28; Petrović 1987: 36). Чини се да семантички, али пре свега когнитивни садржај концепата пријатељь и непријатељ можемо јасно поделити у равни позитивно - негативно или пријатно - непријатно (Драгићевић 2007: 281), те да између њих постоје бројни прелазни случајеви (уп. познаник, колега, партнер и сл.; в. Грицкат 1989: 2; Lyons 1977: 272). На плану теоријског конструкта семантичког поља стереотипа, логички бисмо морали искључити крајњи негативни пол стереотипа пријатеља и позитивни пол стереотипа непријатеља, јер на оси међуљудских односа пријатељски однос може имати негативну раван, тј. на крајњу негативну тачку поставити концепт непријатеља, јер појам пријатеља у проширеном обухвату представља и све прелазне случајеве све до појма непријатеља. Закључујемо да је у оба истраживана језика дошло до промена у семантичком пољу стереотипа пријатеља од традиционалног стереотипа ка трансформисаном стереотипу који сада обухвата и нове типове друштвених и партнерских односа описаних синтагмама слов. priatel' na Facebookulfacebookový priatel', priatel's benefitmi/priatel's výhodami, срп. пријатељь на Фејсбуку и пријатељь с повластицама. У српском језику бележимо и проширени стереотип који је резултат померања 'пријатеља као помагача' из приватне у јавну сферу (срп. пријатељь емисије, руски пријатељи, западни пријатељи и сл.). У словачком језику овај проширени стереотип налази се на самој периферији (уп. више: americký $261 \approx 0,1 \%$ )

На основу представљене грађе и њене анализе можемо закључити да су слика пријатеља у словачкој и она у српској језичкој слици света веома блиске. Да бисмо у овим двема културама некога назвали пријатељем он треба да нам прија, буде нам наклоњен и пружа нам помоћ и подршку онда када нам је потребна, али су овим појмом обухваћени бројне бројне градације и прелази у међуљудским односима: од родбинских, преко интимних, другарских до колегијалних и политичких, све до врло површних - познаничких и др. У обе културе човеку се приступа с пријатељске основе уз свест о могућој промени

${ }^{15}$ Префиксом не- могу се постићи у други, неправи антонимски односи (в. Драгићевић 2007: 284-285; Апресян 1995: 306-316). За актуелан и опсежан преглед истраживања о антонимима в. Јакић 2016: 2-23 и др. 
намера из пријатељских у непријатељске. Фазичност и флуидност међуљудских односа у савременом словачком и српском друштву сами се препоручују да и убудуће буду тема истраживања језичке слике света.

\section{Цитирана литература}

Апресян, Юрий Д. Лексическая семантика: синонимические средства языка. Москва: Языки русской культуры, 1995.

[Apresiān, Iưrǐ̄ D. Leksicheskaiā semantika: sinonimicheskie sredstva iāzyka. Moskva: Iazzyki russkoî kul'tury, 1995]

Грицкат, Ирена. „Прилошке речи посматране кроз феномен антонимије”. Јужнословенски филолог XLV, 1989: 1-26.

[Grickat, Irena. „Priloške reči posmatrane kroz fenomen antonimije”. Južnoslovenski filolog XLV, 1989: 1-26]

Драгићевић, Рајна. Лексикологија српског језика. Београд: Завод за уџбенике, 2007.

[Dragićević, Rajna. Leksikologija srpskog jezika. Beograd: Zavod za udžbenike, 2007]

Јакић, Милена. Придевска антонимија у речнику, контексту и когнитивном систему (докторска дисертација). Београд: Филолошки факултет, 2016.

[Jakić, Milena. Pridevska antonimija u rečniku, kontekstu i kognitivnom sistemu (doktorska disertacija). Beograd: Filološki fakultet, 2016]

Књазев-Адамовић, Светлана, Станиша Новаковић. Логика са методологијом (за IV разред усмереног образовања, за струку делатности у области културе и јавног информисања у преводилачку и архивско-музејску струку). Београд: Завод за уџбенике и наставна средства, 1986.

[Knjazev-Adamović, Svetlana, Staniša Novaković. Logika sa metodologijom (za IV razred usmerenog obrazovanja, za struku delatnosti u oblasti kulture i javnog informisanja u prevodilačku i arhivsko-muzejsku struku). Beograd: Zavod za udžbenike i nastavna sredstva, 1986]

Пауновић Родић, Стефана. Стереотип жене у језичкој слици света Словака и Срба (докторска дисертација). Београд: Филолошки факултет, 2019.

[Paunović Rodić, Stefana. Stereotip žene u jezičkoj slici sveta Slovaka i Srba (doktorska disertacija). Beograd: Filološki fakultet, 2019]

Поповић, Људмила. Језичка слика стварности: когнитивни аспект контрастивне анализе. Београд: Филолошки факултет, 2008.

[Popović, Ljudmila. Jezička slika stvarnosti: kognitivni aspekt kontrastivne analize. Beograd: Filološki fakultet, 2008]

Шмелев, Алексей Д. «Дружба в русской языковой картине мира». [B:] А. А. Зализняк, И. Б. Левонтина, А. Д. Шмелев. Ключевые идеи русской языковой картины мира. Москва: Языки славянской культуры, 2005: 289-303.

[Shmelev, Alekseǐ D. «Druzhba v russkoǔ iazykovoŭ kartine mira». [V:]A. A. Zalizniak, I. B. Levontina, A. D. Shmelev. Kliuchevye idei russkoř iazykovoř kartiny mira. Moskva: Tazyki slavianskoĭ kul'tury, 2005: 289-303]

Lyons, John. Semantics, Volume I. Cambridge, London, New York, Melbourne: Cambridge University Press, 1977.

Petrović, Gajo. Logika. Zagreb: Školska knjiga, 1987.

Wierzbicka, Anna. Understanding Cultures through Their Key Words: English, Russian, Polish, German, and Japanese. New York: Oxford University Press, 1997. 


\section{Извори}

Караџић, Вук Стефановић. Српске народне пословице и друге различне као оне у обичај узете ријечи. Београд: Нолит, 1969.

[Karadžić, Vuk Stefanović. Srpske narodne poslovice i druge različne kao one u običaj uzete riječi. Beograd: Nolit, 1969]

OAP: Рајна Драгићевић, Предраг Пипер, Марија Стефановић. Обратни асоцијативни речник српскога језика Део 2, од реакције ка стимулусу. Београд: Београдска књига, Службени гласник, 2011.

[OAR: Rajna Dragićević, Predrag Piper, Marija Stefanović. Obratni asocijativni rečnik srpskoga jezika Deo 2, od reakcije ka stimulusu. Beograd: Beogradska knjiga, Službeni glasnik, 2011]

PMC I-VI: M. Стевановић, С. Марковић, С. Матић, М. Пешикан. Речник српскохрватскога књижевног језика, Нови Сад: Матица српска (љубљана: Младинска књига), 1990.

[RMS I-VI: M. Stevanović, S. Marković, S. Matić, M. Pešikan. Rečnik srpskohrvatskoga književnog jezika, Novi Sad: Matica srpska (Ljubljana: Mladinska knjiga), 1990]

РСАНУ 1-20: Речник српскохрватског књижевног и народног језика, Београд: Институт за српски језик, Српска акадмија наука и уметности, 1958-.

[RSANU 1-20: Rečnik srpskohrvatskog književnog i narodnog jezika, Beograd: Institut za srpski jezik, Srpska akadmija nauka i umetnosti, 1958-]

PCJ: М. Николић (ур.). Речник српскога језика. Нови Сад: Матица српска, 2011.

[RSJ: M. Nikolić (ur.). Rečnik srpskoga jezika. Novi Sad: Matica srpska, 2011]

Ћосић, Павле и сарадници. Речник синонима. Београд: Kornet, 2008.

[Ćosić, Pavle i saradnici. Rečnik sinonima. Beograd: Kornet, 2008]

ELKK: J. Botík (ved. red.). Encyklpédia l’udovej kultúry Slovenska. Bratislava: Veda, 1995. <https://www.ludovakultura.sk/encyklopedia/> 5. 7. 2021.

Gerzić, Borivoj. Rečnik srpskog žargona. Beograd: B. Gerzić, 2012.

HSSJ: M. Majtán et al. (red.) Historický slovník slovenského jazyka. Bratislava: Veda, 1991-2008. <https://slovnik.juls.savba.sk/> 5. 7. 2021.

Králik, Lubor. Stručný etymologický slovník slovenčiny, Bratislava: Veda, 2015.

KSSJ: J. Kačala, M. Pisárčiková, M. Považaj (red.). Krátky slovník slovenského jazyka. Bratislava: Veda, 2003. <https://slovnik.juls.savba.sk/> 5. 7. 2021.

Machek, Václav. Etymologický slovník jazyka českého a slovenského. Praha: Československá akademie věd. Sekce jazyka a literatury, 1968.

Rejzek, Jiří. Český etymologický slovník. Voznice: Leda, 2001.

Skok I-III: Petar Skok. Etimologijski rječnik hrvatskoga ili srpskoga jezika I-III. Zagreb: Jugoslavenska akademija znanosti i umjetnosti, 1971-1973.

SNK: Slovenský národný korpus - prim-9.0-public-sane. Bratislava: Jazykovedný ústav L. Štúra SAV 2013. <http://korpus.juls.savba.sk>; <https://bonito.korpus.sk/> 5. 7. 2021.

srWaC (Serbian Web): <http://nl.ijs.si/noske/all.cgi/first_form?corpname=srwac;align=> 5. 7. 2021.

SSJ: Š. Peciar (hl. red.). Slovník slovenského jazyka. Bratislava: Vydavatel'stvo Slovenskej akadémie vied. 1959-1968. <https://slovnik.juls.savba.sk/> 5. 7. 2021.

SSSJ: A. Jarošová, K. Buzássyová (ved. red.). Slovník súčasného slovenského jazyka A-N. Bratislava: Veda, 2006, 2011, 2015. <https://slovnik.juls.savba.sk/> 5. 7. 2021. 
SynSS: M. Pisárčiková (red.). Synonymický slovník slovenčiny. Bratislava: Veda, 2004. <https://slovnik.juls.savba.sk/> 5. 7. 2021.

UD: Urban dictionary <https://www.urbandictionary.com/> 5. 7. 2021.

Záturecký, Adolf Peter. Slovenské príslovia, porekadla a úslovia. Bratislava: Tatran, 1975. $<$ http://sc.rs/sc/4-april/> 5. 7. 2021.

$<$ http://www.loviribolovtv.com/o-nama.html > 5. 7. 2021.

$<$ http://www.emisijafarma.rs/> 5. 7. 2021.

$<$ https://www.malidnevnik.rs/cr/> 5. 7. 2021.

$<$ https://beguprirodu.rs/\#prijatelji $>$ 5. 7. 2021.

$<$ https://pureallure.co/tag/tvnasa/> 5. 7. 2021.

$<$ https://direktno.rs/zivot/302738/zeljko-mitrovic-smiljan-banjac-igor-brakus.html $>5.7$. 2021.

$<$ https://grand.online/nikad-nije-kasno/news/u-svaku-sobu-po-televizor-i-da-gledatenikad-nije-kasno-video> 5. 7. 2021.

$<$ https://informer.rs/zabava/kultura/336571/foto-cetvrti-rodjendan-emisije-beogradpoznati-uvelicali-slavlje > 5. 7. 2021.

$<$ https://lat.rtrs.tv/program/tekst.php?id=2284> 5. 7. 2021.

$<$ https://www.rts.rs/page/tv/sr/story/22/rts-svet/3545287/bunt-rok-festival---specijal. html> 5. 7. 2021.

$<$ https:/www.vijesti.me/tv/emisije/487275/dnevnica-sa-ivanom-mrvaljevic-citav-dansa-kacigom-na-glavi> 5. 7. 2021.

\section{Стефана Паунович Родич}

\section{О ДРУГЕ В СЛОВАЦКОЙ И СЕРБСКОЙ ЯЗЫКОВЫХ КАРТИНАХ МИРА}

\section{Резюме}

Целью работы является исследование и описание стереотипа друга в языковых картинах мира словаков и сербов. Анализ проведен на материале словарей, паремиологических примеров и электронных корпусов словацкого и сербского языков. В последнее время можно заметить новые тенденции в употреблении лексемы друг в обоих исследуемых языках - данное слово встречается в словосочетаниях типа: словац. priatel' na facebooku/facebookový priatel', priatelia s benefitmi/priatelia s výhodami; серб. пријатељ емисије, пријатељь на Фејсбуку, пријатељ с повластицама. Данные тенденции подтолкнули нас рассмотреть следующие вопросы: 1) употребляется ли, и если да, то когда, слово друг для обозначения деятеля в сфере общественной жизни; 2) можно ли, и если да, то в каких случаях, назвать другом человека, с которым вступают в интимные отношения; 3) какое влияние оказали социальные сети на расширение понятия друг и, вообще, на коцептуализацию дружеских отношений. Также рассматривается вопрос о том, является ли стереотип врага отрицательно коннотированной составной частью стереотипа друга или же речь идет о разных стереотипах, с различным семантическим наполнением. На основе представленного материала и его анализа делается вывод о том, что новый стереотип друга у сербов и словаков очень похож. В обеих языковых картинах мира друг концептуализируется как личность, рядом с которой себя хорошо чувствуют, как благосклонный человек, оказывающий помощь. Концепты друга и врага вступают в отношение ассиметрической контрарно-координированной оппозиции. Оба понятия принадлежат сфере межличностных отношений, причем понятие друга является более ши- 
роким, охватывая все ступени межличностных отношений (начиная со знакомого или коллеги - и вплоть до любовника).

В обоих исследуемых языках произошли изменения в семантическом поле стереотипа друга - от традиционного к трансформированному, охватывающему новые типы общественных и партнерских отношений. Кроме того, в сербском языке наблюдается расширенный стереотип, возникший в результате сдвига концептуализации друга как помощника из сферы личной жизни в сферу общественных отношений.

Ключевые слова: друг, словацкий язык, сербский язык, когнитивная лингвистика, языковая картина мира, стереотип. 